Haruhiko Hirai · Shigeo Nakajima • Akimitsu Miyauchi

Kumi Nishimura $\cdot$ Nobuhiko Shimizu $\cdot$ Masaaki Shima

Toshimi Michigami $\cdot$ Keiichi Ozono $\cdot$ Shintaro Okada

\title{
A novel activating mutation (C129S) in the calcium-sensing receptor gene in a Japanese family with autosomal dominant hypocalcemia
}

\begin{abstract}
Autosomal dominant hypocalcemia can be caused by activating mutations of the calcium-sensing receptor $(C a S R)$ gene. We experienced two patients (proband and her daughter) with hypocalcemia caused by a missense mutation of the CaSR gene. The proband, aged 25, showed hypocalcemia and hypoparathyroidism from infancy. She had been diagnosed as having idiopathic hypoparathyroidism and had been treated with calcitriol. She gave birth to a female infant at age 24 years. Her daughter was found to have hypocalcemia $(\mathrm{Ca}, 6.6 \mathrm{mg} / \mathrm{dl})$, without seizure or tetany, when she was 7 months old. DNA analysis of their CaSR genes showed a novel heterozygous mutation at codon 129 (TGC-to-AGC) with substitution of cysteine for serine (C129S). Familial examination revealed that this mutation had occurred de-novo in the proband. Wild-type and mutant (C129S) CaSR cDNA were transfected into HEK293 cells, and intracellular calcium concentrations were measured with a fluorescent calcium indicator. HEK cells transfected with the C129S mutant CaSR gene showed a larger increase in intracellular calcium concentration in response to the change in the extracellular calcium concentration than HEK cells transfected with the wild-type receptor. We conclude that the $\mathrm{C} 129 \mathrm{~S}$ mutation in the CaSR gene observed in these patients causes autosomal dominant hypocalcemia.
\end{abstract}

Key words Calcium-sensing receptor - Autosomal dominant hypocalcemia $\cdot$ Hypoparathyroidism $\cdot$ Missense mutation · Intracellular calcium

H. Hirai, S. Nakajima $(\bowtie) \cdot$ K. Nishimura $\cdot$ N. Shimizu $\cdot$ M. Shima S. Okada

Department of Pediatrics, D-5, Developmental Medicine, Osaka University Graduate School of Medicine, 2-2 Yamadaoka, Suita, Osaka 565-0871, Japan

Tel. +81-6-6879-3932; Fax +81-6-6879-3939

e-mail: nakajima@ped.med.osaka-u.ac.jp

A. Miyauchi

National Sanatorium Hyogo Chuo Hospital, Hyogo, Japan

T. Michigami $\cdot$ K. Ozono

Department of Environmental Medicine, Osaka Medical Center and

Research Institute for Maternal and Child Health, Osaka, Japan

\section{Introduction}

The calcium-sensing receptor (CaSR) is a member of the seven-transmembrane domain G-protein-coupled receptor superfamily. With mutations of the CaSR gene, hypercalcemia or hypocalcemia can occur (Brown et al. 1993; Garrett et al. 1995). Mutations in the CaSR gene that cause gain in the receptor function have been reported in patients with autosomal dominant hypocalcemia (Mancilla et al.1997; Lovlie et al. 1996; Pearce et al. 1996b; Okazaki et al. 1999) and in sporadic hypocalcemia (Baron et al. 1996; De Luka et al. 1997). Even when extracellular calcium concentration declines, CaSR with activating mutations inappropriately suppresses the secretion of parathyroid hormone, which increases serum calcium levels, resulting in hypocalcemia. In previous reports, mutations that cause autosomal dominant hypocalcemia have been detected in the extacellular domain of the proximal amino-terminal region or the transmembrane region of the receptor. We experienced familial hypocalcemia (proband and her daughter), and confirmed by DNA analysis that a novel mutation at codon129 of CaSR had occurred in the proband, and was transmitted to her daughter.

\section{Patients and methods}

The proband (case 1) was a 25 -year-old woman. She had manifested hypocalcemia in infancy. From seven months of age, she had experienced convulsions and was diagnosed as having epilepsy. When she was 8 years old, she visited our hospital and showed hypocalcemia $(\mathrm{Ca}, 6.0 \mathrm{mg} / \mathrm{dl})$ and hyperphosphatemia (inorganic[i]P, $10.2 \mathrm{mg} / \mathrm{dl}$ ). EllsworthHoward test showed a normal response of urinary cyclic adenosine morophosphate (cAMP) excretion. Thus, she was diagnosed as having idiopathic hypoparathyroidism, and calcitriol therapy was started. When she was 19 years old, she had nephrocalcinosis and her serum creatinine level was increased, to $1.3 \mathrm{mg} / \mathrm{dl}$. At the age of 24 years, she gave 
birth to a female infant (case 2). The daughter was asymptomatic during early infancy. When she was 7 months old, she was found to have hypocalcemia $(\mathrm{Ca}, 6.6 \mathrm{mg} / \mathrm{dl})$ and hyperphosphatemia (iP, $9.5 \mathrm{mg} / \mathrm{dl})$. Her intact parathyroid hormone $(\mathrm{PTH})$ level was below the normal range $(<5 \mathrm{pg} /$ $\mathrm{ml}$ ). The urinary calcium/creatinine ratio in the proband and her daughter exceeded 0.21 , when serum calcium concentrations were $7.0 \mathrm{mg} / \mathrm{dl}$ in case 1 and $8.4 \mathrm{mg} / \mathrm{dl}$ in case 2 .

Because the disease was apparently transmitted in a dominant form, we performed DNA analysis of the CaSR gene after obtaining written informed consent from the patient for herself and her daughter. Lymphocytes were collected from heparinized peripheral blood samples and DNA was extracted with the Sepa Gene kit (Sanko Jyunyaku, Tokyo, Japan). Exon 2 to exon 7 of the CaSR gene, which codes the entire the $C a S R$, were amplified by the polymerase chain reaction (PCR) procedure (Pollak et al. 1993). The PCR products were analyzed with the ABI PRISM 310 Genetic Analyzer (PE Applied Biosystems, Foster City, CA, USA), and the entire sequence of the coding region of the CaSR gene was determined. For expression experiments, wild-type $C a S R$ cDNA was inserted into a pcDNA3 vector (pcDNA3CaSR) (Invitrogen, Carlbad, CA, USA), and a mutant expression plasmid was constructed by in-vitro site-directed mutagenesis (Gene Editor in vitro Site-Directed Mutagenesis System, Promega, Madison, WI, USA) to replace cysteine-129 to serine (pcDNA3CaSR-C129S). HEK293 cells were transfected with the wild-type or the mutant plasmid, and stable cell lines expressing receptors were selected by adding G418 to the culture medium. We measured the cytosolic calcium changes in single cells as described previously (Miyauchi et al. 2000). Briefly, HEK293 cells expressing either wild-type or mutant $C a S R$ were cultured for 1 to 2 days on glass cover slips and loaded with $5 \mu \mathrm{M}$ fura 2-AM (Dojindo Laboratories, Kumamoto, Japan), a fluorescent calcium indicator, for $1 \mathrm{~h}$ at $25^{\circ} \mathrm{C}$ in the bath solution $(126 \mathrm{mM} \mathrm{NaCl}, 5 \mathrm{mM} \mathrm{KCl}$, $1 \mathrm{mMmgCl}_{2}, 0.5 \mathrm{mM} \mathrm{CaCl}_{2}, 20 \mathrm{mM} \mathrm{Na}$-hydroxyethylpiperazine ethanesulfonic acid [HEPES] ( $\mathrm{pH} 7.4)$, and $0.5 \%$ bovine serum albumin). The measuring chamber was mounted on a microfluorometric system, and images were collected at wavelengths of $340 \mathrm{~nm}$ (F340) and 360nm (F360). The F340/F360 ratio, constructed after background image subtraction, disclosed the intracellular $\mathrm{Ca}^{2+}\left(\left[\mathrm{Ca}^{2+}\right]_{\mathrm{i}}\right)$ localization. The average cell $\left[\mathrm{Ca}^{2+}\right]_{\mathrm{i}}$ values were calculated from the calibration curve as previously described (Miyauchi et al. 2000). High extracellular $\mathrm{Ca}^{2+}$ challenge was performed by replacing the medium with other media at various $\mathrm{Ca}^{2+}$ concentrations.

\section{Results and discussion}

DNA analysis revealed that the $C a S R$ gene in both the proband and her daughter had a heterozygous mutation in exon 2 at codon 129 (TGC-to-AGC) (Fig. 1A) that caused a substitution of the amino acid cysteine to serine. This substitution created an $A l w \mathrm{~N} 1$ restriction site. Examination
A)

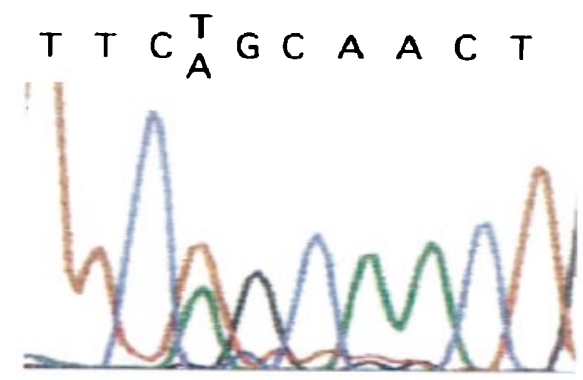

B)

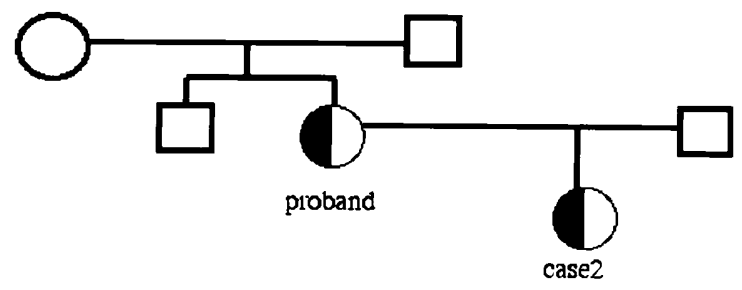

Fig. 1. A DNA analysis of the CaSR gene in case 1. Entire coding regions of the $C a S R$ gene were amplified by polymerase chain reaction (PCR) from the genomic DNA of the patients, and the DNA sequence was determined by the direct sequence method. A heterozygous mutation at codon 129 (TGC-to-AGC) was revealed in case 1 . The same mutation was seen in case 2. B Pedigree of the patients. Mutation of the CaSR gene was detected only in the affected members of the family (the proband and her daughter)

of the parents and the brother of the proband (Fig. 1B) with enzyme-based and direct sequence analysis revealed that this mutation had occurred in the proband de novo. We did not find this mutation in 100 alleles in 50 healthy volunteers without hypocalcemia. In addition, this nucleotide change did not exist in more than 100 normal subjects (Heath et al.1996). In the expression experiments, high extracellular $\mathrm{Ca}^{2+}(0.5$ to $5 \mathrm{mM})$ caused a rapid and sustained increase of $\left[\mathrm{Ca}^{2+}\right]_{\mathrm{i}}$ in both HEK293 cells expressing C129S and wildtype $C a S R$. The net increase in $\left[\mathrm{Ca}^{2+}\right]_{\mathrm{i}}$ was dependent on the change in extracellular $\mathrm{Ca}^{2+}$. The dose-response curve to extracellular $\mathrm{Ca}^{2+}$ in the HEK293 cells expressing C129S mutant $C a S R$ was shifted to the left, with effective concentrations (EC) 50 values of approximately $0.8 \mathrm{mM}$, compared with the wild-type transfectant EC 50 value of approximately $2.2 \mathrm{mM}$ ) (Fig. 2). Thus, to our knowledge, this is the first report that the mutation at cysteine-129 of the CaSR gene (Fig. 3) causes autosomal dominant hypocalcemia.

Extracellular calcium concentration is regulated mainly by PTH secretion from the parathyroid gland. CaSR senses extracellular calcium concentration and regulates PTH synthesis. PTH secretion is inappropriately suppressed with lower extracellular calcium concentration by activating mutations of CaSR. Although, at present, it is still not clear whether CaSR exists as a dimer in the cell membrane or not (Bai et al. 1998), Watanabe et al. (1998) demonstrated that the co-expression of the wild-type and the activating mutant CaSR shifted the set-point of the extracellular calcium concentration to almost equivalent to that observed 
Fig. 2. Functional analysis of wild-type (WT) and mutant $\mathrm{C} 129 \mathrm{~S}$ CaSR. HEK293 cells expressing wild-type or mutant $C a S R$ were grown on a slide glass, and the change in the intracellular calcium concentration was measured in a single cell. Values for results were expressed as means \pm SEM.

The number of experiments is indicated in parentheses

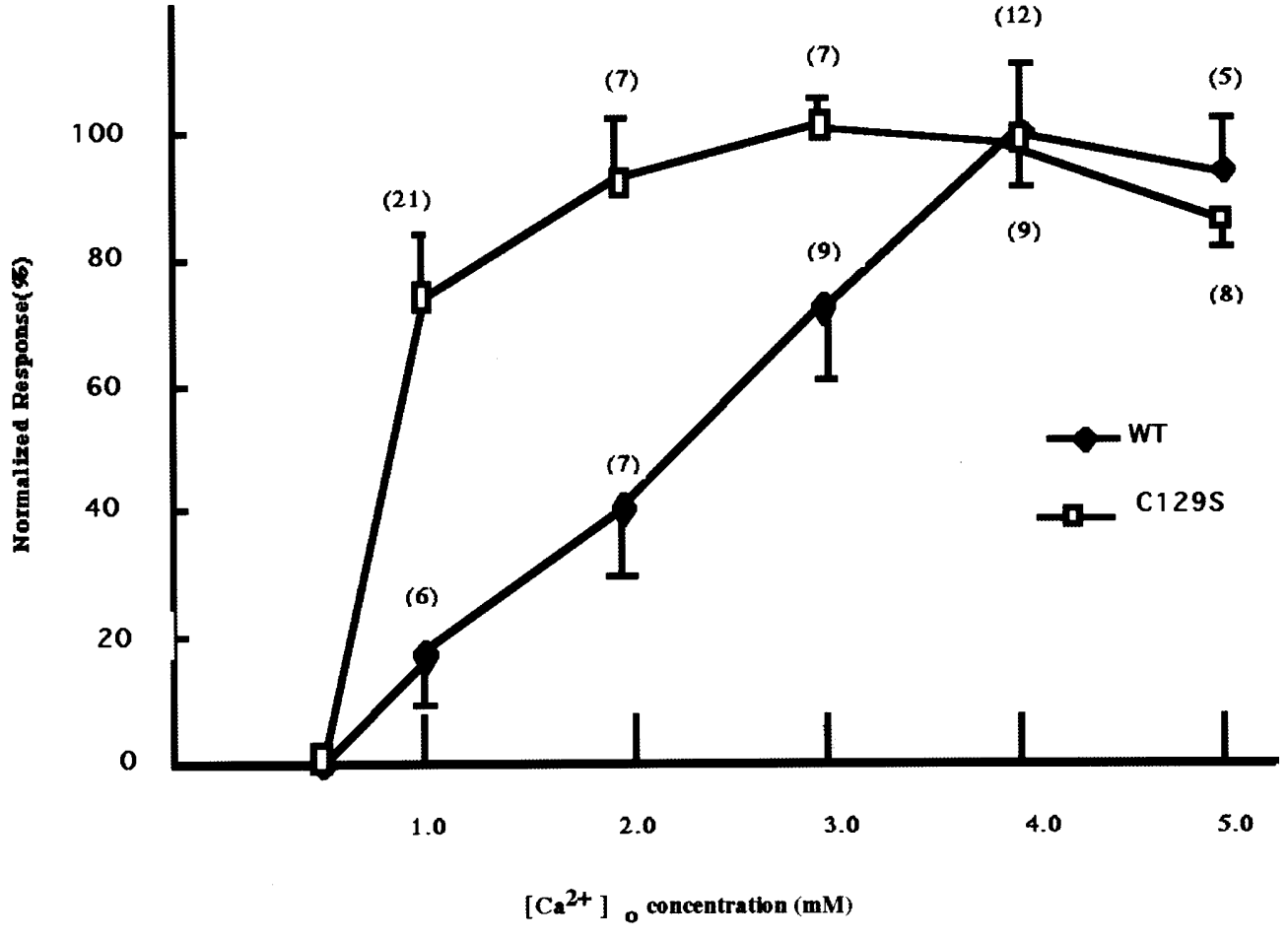

Fig. 3. Portions of activating mutations in CaSR. Activating mutations reported previously existed at the $\mathrm{N}$-terminal in the extracellular domain or in the transmembrane domain. The mutation in our cases (probond and her daughter) exists at the $\mathrm{N}$-terminal in the extracellular domain

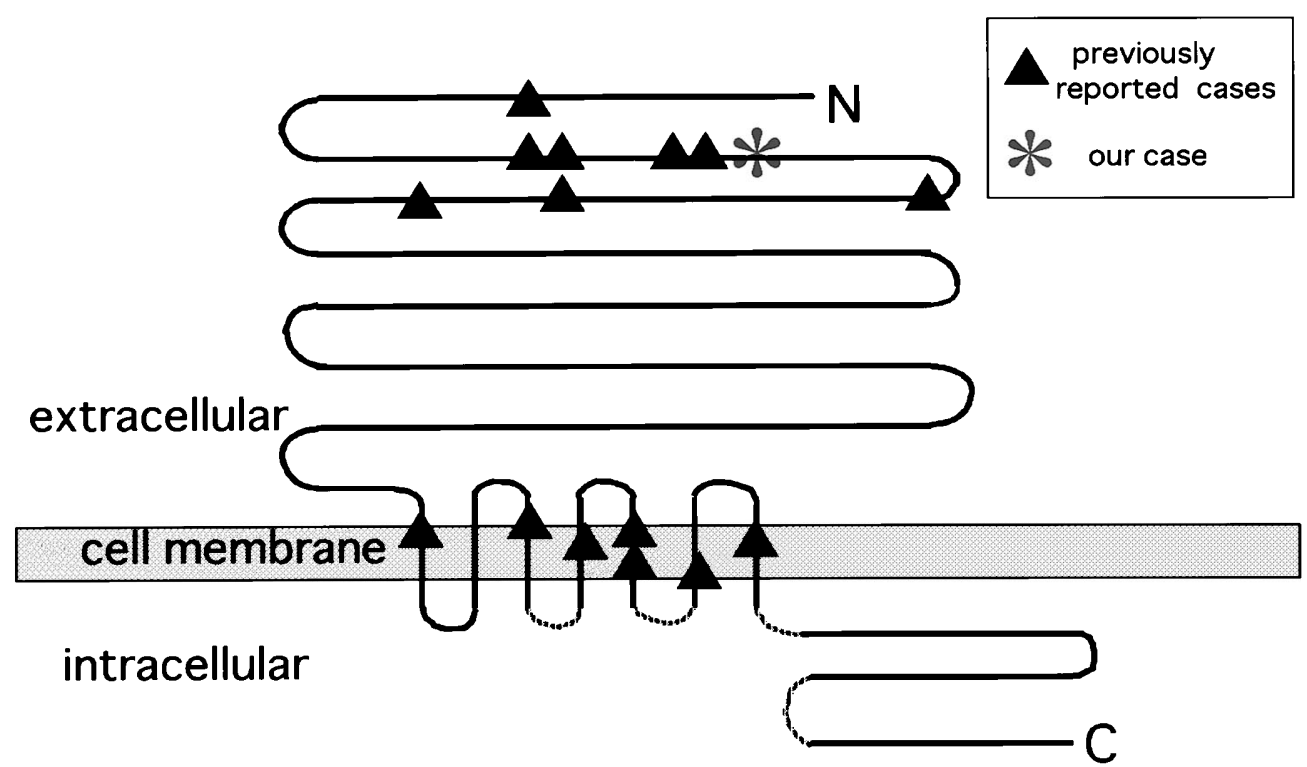

with mutant receptor alone. Taken together, these findings indicate that the activating mutation of the $C a S R$ gene in one allele causes the hypocalcemia inherited in autosomal dominant form.

The extracellular domain of $C a S R$ does not contain the consensus sequences proposed for high-affinity $\mathrm{Ca}^{2+}$ binding sites, but a low-affinity $\mathrm{Ca}^{2+}$ binding site does exist in this domain (Brown et al.1993). The precise mechanism by which $C a S R$ transmits the change in the extracellular calcium concentration is unknown, but the low-affinity $\mathrm{Ca}^{2+}$ binding site may play a significant role. Point mutations of glutamic acid-127 (Pollak et al.1994) and phenylalanine-128 (Pearce et al. 1996a) were previously reported to cause autosomal dominant hypocalcemia. Because the mutation we report here was located at codon 129 , this region seems to be significant in regard to the binding to extracellular calcium. Previously, hypocalcemia was reported to be more severe in patients with mutations in the transmembrane domain than in those with mutations in the extracellular domain of the CaSR gene (Watanabe et al. 1998). Considering that the proband presented here apparently manifested more severe symptoms than her daughter, the severity of 
autosomal dominant hypocalcemia seems to be determined not only by the type of mutation but also by other factors, such as the calcium nutritional status.

In conclusion, the novel point mutation at cysteine-129 in the extracellular domain of CaSR causes autosomal dominant hypocalcemia, and this result indicates that this amino acid plays an important role in binding to extracellular calcium ions.

Acknowledgments We thank Dr. J. Garrett, of NPS Pharmaceuticals, for providing plasmid $\mathrm{pcDNAl} / \mathrm{hpCaR}-8$. We gratefully acknowledge Dr. N. Nagano of Kirin Brewery for useful advice and Ms Ok-Soon Park for expert secretarial assistance.

\section{References}

Bai M, Trivedi S, Brown EM (1998) Dimerization of the extracellular calcium-sensing receptor $(\mathrm{CaR})$ on the cell surface of $\mathrm{CaR}$ transfected HEK293 cells. J Biol Chem 273:23605-23610

Baron J, Winer KK, Yanovski JA, Cunningham AW, Laue L, Zimmerman D, Cutler GB (1996) Mutations in the $\mathrm{Ca}^{2+}$-sensing receptor gene cause autosomal dominant and sporadic hypoparathyroidism. Hum Mol Genet 5:601-606

Brown EM, Gamga G, Ricccardi D, Lombardi M, Butters R, Kifor O, Sun A, Hediger MA, Lytton J, Herbert SC (1993) Cloning and characterization of an extracellular $\mathrm{Ca}^{2+}$-sensing receptor from bovine parathyroid. Nature 366:575-580

De Luca F, Ray K, Mancilla EE, Fan GF, Winer KK, Gore P, Spiegel AM, Baron J (1997) Sporadic hypoparathyroidism caused by de novo gain-of-function mutations of the $\mathrm{Ca}^{2+}$-sensing receptor. J Clin Endocrinol Metab 82:2710-2715

Garrett JE, Capuano IV, Hammerland LG, Hung BCP, Brown EM, Herbert SC, Nemeth EF, Fuller F (1995) Molecular cloning and functional expression of human parathyroid calcium receptor cDNAs. J Biol Chem 270:12919-12925

Heath H III, Odelberg S, Jackson CE, Teh BT, Hayward N, Larsson C, Buist NRM, Krapcho KJ, Hung BC, Capuano IV, Garrett JE,
Leppert MF (1996) Clustered inactivating mutations and benign polymorphisms of the calcium receptor gene in familial benign hypocalciuric hypercalcemia suggest receptor functional domains. J Clin Endocrinol Metab 81:1312-1317

Lovlie R, Eiken HG, Sorheim JI, Boman H (1996) The $\mathrm{Ca}^{2+}$-sensing receptor gene (PCAR1) mutation T151M in isolated autosomal dominant hypoparathyroidism. Hum Genet 98:129-133

Mancilla EE, De Luca F, Ray K, Winer KK, Fan G, Baron J (1997) A $\mathrm{Ca}^{2+}$-sensing receptor mutation causes hypoparathyroidism by increasing receptor sensitivity to $\mathrm{Ca}^{2+}$ and maximal signal transduction. Pediatr Res 42:443-447

Miyauchi A, Notoya K, Mikuni-Takagaki Y, Takagi Y, Goto M, Miki Y, Takano-Yamamoto T, Jinnai K, Takahashi K, Kumegawa M, Chihara K, Fujita T (2000) Parathyroid hormone-activated volumesensitive calcium influx pathways in mechanically loaded osteocytes. J Biol Chem 275:3335-3342

Okazaki R, Chikatsu N, Nakatsu M, Takeuchi Y, Ajima M, Miki J, Fujita T, Arai M, Totsuka Y, Tanaka K, Fukumoto S (1999) A novel activating mutation in calcium-sensing receptor gene associated with a family of autosomal dominant hypocalcemia. J Clin Endocrinol Metab 84:3363-3366

Pearce SHS, Bai M, Quinn SJ, Kifor O, Brown EM, Thakker RV (1996a) Functional characterization of calcium-sensing receptor mutations expressed in human embryonic kidney cells. J Clin Invest 98:1860-1866

Pearce SHS, Williamson C, Kifor O, Bai M, Coulthard MG, Davies M, Lewis-Barned N, McCredie D, Powell H, Kendall-Taylor P, Brown EM, Thakker RV (1996b) A familial syndrome of hypocalcemia with hypercalciuria due to mutations in the calcium-sensing receptor. $\mathrm{N}$ Engl J Med 335:1115-1122

Pollak MR, Brown EM, Chou Y-HW, Hebert SC, Marx SJ, Steinmann B, Levi T, Seidman CE, Seidman JG (1993) Cell mutations in the human $\mathrm{Ca}^{2+}$-sensing receptor gene cause familial hypocalciuric hypercalcemia and neonatal severe hyperparathyroidism. Cell 75: 1297-1303

Pollak MR, Brown EM, Estep HL, McLaine PN, Kifor O, Park Ji, Herbert SC, Seidman CE, Seidman JG (1994) Autosomal dominant hypocalcaemia caused by a $\mathrm{Ca}^{2+}$-sensing receptor gene mutation. Nat Genet 8:303-307

Watanabe T, Bai M, Lane CR, Matsumoto S, Minamitani K, Minagawa M, Niimi H, Brown EM, Yasuda T (1998) Familial hypoparathyroidism: identification of a novel gain of function mutation in transmembrane domain 5 of the calcium-sensing receptor. J Clin Endocrinol Metab 83:2497-2502 